\title{
Koping Religius dan Stres pada Guru Sekolah Islam
}

\author{
Ratna Supradewi \\ Fakultas Psikologi Universitas Islam Sultan Agung Semarang \\ ratnavina4@gmail.com
}

\begin{abstract}
Abstrak
Fenomena stres pada guru telah mendapat perhatian dan kepedulian global yang meningkat dalam beberapa tahun terakhir. Saat menghadapi tekanan dan situasi yang penuh stres individu akan melakukan koping yang merupakan cara mengelola stres. Salah satu koping yang dilakukan individu adalah dengan koping religius. Penelitian ini bertujuan untuk menguji secara empiris hubungan koping religius dengan stres yang dialami guru. Subjek penelitian adalah guru sekolah Islam dari SMU Sultan Agung 1 dan SMU Sultan Agung 3 Semarang berjumlah 71 orang. Teknik pengambilan sampel yang digunakan adalah purposive sampling. Skala yang dipakai pada penelitian ini adalah skala koping religius dan skala stres guru. Analisis data menggunakan teknik korelasi Product Moment dari Pearson. Dari hasil analisis data diperoleh nilai $r x y=-0,540$ dengan signifikansi $0,000(p<0,005)$. Hasil penelitian tersebut menunjukkan ada hubungan negatif yang signifikan antara koping religius dengan stres pada guru. Koping religius memberikan kontribusi sebesar 29,2\% terhadap stres guru, sedangkan 70,8\% dipengaruhi variabel lain yang tidak diteliti pada penelitian ini.
\end{abstract}

Keyword: koping religius, stres guru, sekolah islam

\begin{abstract}
The phenomenon of stress on teachers has received increasing attention and global concern in recent. years. When faced with pressure and stressful situations individuals will do coping which is a way to manage stress. One of the coping done by individuals is religious coping. This study aims to empirically examine the relationship of religious coping with stress experienced by teachers. The research subjects were Islamic school teachers from Sultan Agung 1 High School and Sultan Agung 3 Semarang High School, amounting to 71 people. The sampling technique used was purposive sampling. The scale used in this study is the religious coping scale and the teacher's stress scale. Data analysis using Product Moment correlation techniques from Pearson. From the results of data analysis, the value of $r x y=-$ 0.540 was obtained with a significance of $0,000(p<0.005)$. The results of this study indicate that there is a significant negative relationship between religious coping with stress on the teacher. Religious coping contributed $29.2 \%$ to teacher stress, while $70.8 \%$ was influenced by other variables not examined in this study.
\end{abstract}

Keyword: religious koping, teacher stress, Islamic school 
PSISULA: Prosiding Berkala Psikologi

Vol. 1, 2019

E-ISSN: 2715-002X

\section{Pendahuluan}

Sejak tahun 1970-an telah mulai dilakukan penelitian mengenai stres kerja, termasuk stres kerja di kalangan guru. Chan, Chen, \& Chong (2010) mengemukakan bahwa fenomena masalah stres pada guru merupakan masalah global dan tidak terbatas pada negara tertentu. Beberapa penelitian telah dilakukan untuk menguji prevalensi, tingkat, dan sumber utama stres di kalangan guru sekolah di Inggris, Malta, New South Wales, Pakistan, Amerika Serikat, Welsh, India Barat, dan Hongkong.

Guru merupakan aset utama negara. Tugas guru adalah mencerdaskan anak didik sebagai harapan bangsa di masa depan. Dalam melaksanakan tugasnya guru rentan menghadapi stres kerja. Menurut Khan dkk, (2012) dalam proses memenuhi harapan, tugas dan tanggung jawabnya, para guru dapat terkena dampak faktor lingkungan internal atau eksternal tertentu yang tidak diinginkan, yang menghambat kemampuan rutin mereka dan hasilnya adalah pengembangan perasaan kelelahan dan ketegangan. Kyriacou (2001) mengemukakan stres guru merupakan pengalaman yang tidak menyenangkan, emosi negatif, kemarahan, kegelisahan, ketegangan frustrasi, dan depresi akibat dari beberapa aspek dari pekerjaan mereka sebagai seorang guru. Stres kerja akan berdampak buruk dan menurunkan kinerja individu yang bersangkutan.

Stres kerja pada guru dapat mempunyai dampak negatif, baik bagi guru maupun kualitas pendidikan. Konsekuensi yang mungkin timbul dari stres guru adalah berkurangnya self-efficacy guru (Klassen dkk, 2013), rendahnya kepuasan kerja (Collie, Shapka, \& Perry, 2012), rendahnya level komitmen (Klassen dkk, 2013), tingginya level burnout (Betoret, 2009), dan penurunan semangatguru (Skaalvik \& Skaalvik, 2011). Efek negatif dari stres akademik terhadap kesejahteraan psikologis juga dilaporkan Blix dan Mitchell (2004) menyatakan bahwa hampir setengah dari responden mereka melaporkan masalah kesehatan psikologis yang diakibatkan stres kerja dan 48\% menganggap bahwa produktivitas dan kinerjanya telah terpengaruh secara negatif. 
PSISULA: Prosiding Berkala Psikologi

Vol. 1, 2019

E-ISSN: 2715-002X

Saat menghadapi situasi yang penuh stres umumnya individu akan melakukan koping. Koping ada dua macam, bersifat non religius dan religius. Menurut Pargament (1997) koping religius adalah suatu kerangka yang didasarkan pada pendekatan individu ketika memecahkan permasalahan dalam konteks hubungannya dengan Tuhan. Pargament dkk (1998) mengungkapkan pengukuran koping religius telah terbukti sebagai prediktor yang lebih kuat dalam menghadapi situasi yang penuh stres. Pargament (Kasberger, 2002) mengemukakan agama mempunyai fungsi penting dalam pengelolaan stres karena agama dapat memberikan individu pengarahan/ bimbingan, dukungan, dan harapan. Rammohan, Rao, dan Subbakrishna (2002) mengungkapkan melalui berdoa, ritual, dan keyakinan terhadap agamanya dapat membantu seseorang dalam koping pada saat mengalami stres kehidupan, karena adanya pengharapan dan kenyamanan. Tujuan penelitian ini adalah untuk mengetahui stres guru ditinjau dari koping religius yang dimilikinya.

\section{Stres pada Guru}

Menurut Hayward (Curtis, 2000) stres adalah istilah ambigu yang digunakan dengan berbagai cara untuk untuk menggambarkan situasi, objek atau orang yang menyebabkan stres, perasaan dan respon fisik yang terjadi pada diri individu, dan hasil yang diakibatkan berupa perilaku, kognisi, atau fisiologis. Curtis (2000) mengungkapkan perlu dibedakan antara stresor, respon stres, dan stres. Stresor adalah peristiwa atau kejadian yang dipersepsi individu sebagai membahayakan fisik atau kesejahteraan psikologis individu yang bersangkutan. Dalam hal ini dapat berupa hal-hal yang bersifat internal (misal: sakit), eksternal (misal : perubahan lingkungan seperti panas, kepadatan, atau kebisingan), atau sosial (misal: harus menyampaikan suatu pidato di depan umum).

Respon stres mengacu pada reaksi terhadap peristiwa atau kejadian dan melibatkan perubahan-perubahan jasmani yang dipersiapkan untuk keadaan darurat ( respon melawan atau lari) maupun reaksi-reaksi psikologis seperti : cemas, marah dan agresi, apati dan depresi, serta pelemahan kognitif. Stres adalah suatu 
PSISULA: Prosiding Berkala Psikologi

Vol. 1, 2019

E-ISSN: 2715-002X

keadaan yang terjadi di mana individu berhadapan dengan situasi yang dipersepsikan sebagai membahayakan fisik atau kesejahteraan psikologis mereka (Curtis, 2000 ; Nevid, Rathus \& Greene, 2005).

Menurut Taylor (1995) ada beberapa macam respon terhadap stres dan respon itu akan berakibat secara fisiologis, kognitif, emosional, dan perilaku. Respon-respon tersebut sebagai berikut : 1) Respon fisiologis. Respon fisiologis umumnya melibatkan sistem saraf dan kelenjar endokrin. Stres mengakibatkan sistem saraf simpatik menjadi aktif, sehingga tekanan darah meningkat, detak jantung lebih cepat, konduksi kulit meningkat, dan pernafasan juga bertambah. Ini terlihat antara lain ketika individu dihadapkan pada keadaan yang membuat stres, tiba-tiba wajahnya memucat, berkeringat dingin, jantung berdebar keras, dan sebagainya, 2) Respon kognitif. Respon kognitif terhadap stres meliputi hasil-hasil dari proses penilaian dan kemampuan kontrol individu. Respon stres kognitif antara lain kebingungan dan ketidakmampuan berkonsentrasi, gangguan performansi pada tugas-tugas kognitif, pikiran-pikiran tak wajar, intrusif, dan berulang, 3) Respon emosional meliputi ketakutan, kecemasan, merasa malu, marah, depresi, dan juga sikap yang sabar, tabah, atau penyangkalan, 4) Respon perilaku. Dua kategori yang umum dari respon perilaku adalah melawan stresor (fight) atau melarikan diri dari ancaman (flight).

\section{Stres Guru}

Stres guru pertama kali dikemukakan dan diteliti oleh Kyriacou (1987). Stres guru merupakan keadaan emosi negatif yang tidak menyenangkan, seperti kemarahan, frustrasi, kecemasan, depresi, dan kegugupan yang dialami guru karena beberapa aspek dari pekerjaan mereka (Kyriacou, 2001). Stres guru seringkali didefinisikan sebagai pengalaman emosi yang tidak menyenangkan yang dihasilkan dari aspek-aspek pekerjaannya sebagai guru (Kyriacou,2001; Liu \& Onwuegbuzie, 2012). Konseptualisasi stres guru ini telah menyebabkan para peneliti mengeksplorasi aspek-aspek situasi kerja yang dipersepsikan sebagai pengalaman 
PSISULA: Prosiding Berkala Psikologi

Vol. 1, 2019

E-ISSN: 2715-002X

yang penuh stres oleh guru. Aspek-aspek ini sering disebut sebagai stresor (Betoret, 2006), atau tuntuntan kerja (Hakanen, Bakker, \& Schaufeli, 2006).

Sejumlah potensi stres yang menyebabkan stres pada guru telah diidentifikasi dalam studi empiris, antara lain : masalah perilaku atau disiplin siswa, tekanan waktu dan beban kerja, motivasi siswa yang buruk, keragaman siswa yang besar, konflik dengan rekan kerja, kurangnya dukungan administratif, dan konflik nilai (Betoret, 2009; Fernet dkk, 2012; Hakanen dkk, 2006; Klassen \& Chiu, 2011 ; Kokkinos, 2007; Skaalvik \& Skaalvik, 2016). Stres pada guru dapat memiliki konsekuensi yang buruk, baik pada guru yang bersangkutan maupun kualitas pendidikan. Konsekuensi yang mungkin timbul dari stres guru adalah berkurangnya self-efficacy guru (Klassen dkk, 2013), rendahnya kepuasan kerja (Collie, Shapka, \& Perry, 2012), rendahnya komitmen (Klassen dkk, 2013), tingginya level burnout (Betoret, 2009), dan penurunan semangat guru (Skalalvik \& Skaalvik, 2011).

Profesi guru adalah profesi pelayanan yang mengandung potensi mengalami stres kuat dan pemicu munculnya stres dalam pekerjaannya (Loekmono, 2005). Hasil Penelitian “The Professional Teacher Union Of Hong Kong” tahun 1995 (dalam Loekmono, 2005) terhadap 1.100 orang guru-guru di Hongkong yang dibagikan kuesioner secara random sampling didapatkan hasil penelitian bahwa $66 \%$ responden mengalami stres pada tingkat "sangat kuat". Hal ini disebabkan beberapa hal antara lain : sikap siswa yang tidak sesuai aturan, kelas yang terlalu besar, terlalu banyak aturan serta tingginya beban kerja.

Guru yang mengalami emosi negatif selama menjalankan tugas, seperti : kekecewaan, kemarahan, ketegangan, keresahan, berpotensi sangat kuat untuk mengalami stres (Liu \& Onwuegbuzie, 2012). Hasil penelitian Toisuta dan Loekmono (2017) tentang stres guru pendidikan agama di Sekolah Menengah Ambon dari 117 subjek penelitian terdapat 10 orang $(8,55 \%)$ dalam kategori sangat tinggi dan 29 orang $(24,78 \%)$ dalam kategori tinggi.

Ada beberapa alat ukur untuk mengukur tingkat stres guru antara lain : 1) Scale Stress Questionnaire (SSQ) ; 2) Administrative Stress Indeks (ASI) yang dikembangkan Gmelth \& Swent (1982). Loekmono (1999) juga telah membuat skala 
PSISULA: Prosiding Berkala Psikologi

Vol. 1, 2019

E-ISSN: 2715-002X

stres kerja guru, berdasarkan 4 aspek, yaitu : 1) Perilaku peserta didik, 2) Suasana pekerjaan, 3) Tekanan waktu, 4) Etos kerja. Pada penelitian ini peneliti menggunakan skala stres kerja guru yang mengacu pada aspek-aspek yang dikemukakan oleh Loekmono. Pada saat mengalami kondisi yang penuh stres maka individu akan melakukan koping (pengelolaan stres).

\section{Koping Religius}

Glock \& Stark (dalam Ancok dan Suroso, 2008) menartikan agama sebagai sistem simbol, sistem keyakinan, sistem nilai, dan sistem perilaku yang terlembagakan yang semuanya itu berpusat pada persoalan-persoalan yang dihayati sebagai yang paling maknawi (ultimate meaning). Religiusitas berasal dari kata religion atau agama. Menurut English \& English (Loewnthal, 2008) agama adalah sistem nilai, praktik, ritual, upacara dan keyakinan di mana individu dan komunitas menempatkan diri mereka dalam hubungan dengan Tuhan atau ke dunia supranatural, dan seringkali satu sama lain mendapatkan satu set nilai-nilai dengan menilai peristiwa-peristiwa yang terjadi di dunia.

Koping religius adalah koping yang melibatkan penggunaan kognisi dan strategi perilaku yang didasarkan pada kepercayaan atau praktek - praktek religi untuk mengelola stres emosional atau ketidaknyamanan fisik (Knoeig, 1994). Koping religius melibatkan berbagai cara orang-orang menggunakan religi dan kepercayaan mereka untuk mengelola situasi yang penuh stress. Pargament telah menjadi peneliti utama di bidang koping religious sejak diterbitkan bukunya pada tahun 1997 "The Psychology of Religion and Coping", dan banyak studi telah dilakukan mengenai dampak koping religius terhadap kesejahteraan psikologis (Aflakseir \& Coleman, 2011).

Beberapa studi menemukan bahwa koping religius mempunyai efek positif pada mental dan fisik selama periode yang penuh stres (Pargament dalam AbraidoLanza dkk., 2004). Studi kualitatif dan deskriptif menunjukkan bahwa berdoa merupakan suatu bentuk aktif dalam mencari pertolongan (Guarnacia dalam Abraido-Lanza dkk., 2004). Penelitian dengan subjek wanita-wanita Latin yang 
PSISULA: Prosiding Berkala Psikologi

Vol. 1, 2019

E-ISSN: 2715-002X

menderita penyakit radang sendi melaporkan bahwa kepercayaan religius yang dimiliki dapat membantu responden untuk melawan penyakitnya. Responden memaparkan bahwa bagaimana keyakinan mereka terhadap Tuhan membantu mengatasi nyeri dan kesakitan dan membantu menguasai penyakit mereka (Abraido-Lanza dkk., 2004). Menurut Pargament dan Park (Abraido-Lanza dkk., 2004) rasa bekerja sama dengan Tuhan memberdayakan, melalui interaksi dengan Yang Maha Kuasa, individu merasakan bertambahnya kekuatan personal dan efikasi.

Studi mengenai koping religius mula-mula banyak dilakukan di negara-negara yang didominasi budaya Yahudi-Kristen. Namun studi mengenai koping religius selanjutnya juga dilakukan pada negara-negara yang penduduknya mayoritas muslim. Dalam literatur Islam ada penekanan keyakinan mengenai keyakinan agama dan praktek-praktek religi dapat digunakan sebagai sumber daya untuk menghadapi kesulitan hidup. Islam mengajarkan orang untuk bersabar, berdoa, percaya dan kembali kepada Tuhan saat membutuhkan bimbingan dan pertolongan (Alflakseir \& Coleman, 2011).

Berbagai sumber religi Islam, khususnya Al-Qur'an, memberikan pengarahan tertentu agar perasaan menjadi lebih baik dan mengatasi kesulitan dengan cara mengingat Tuhan atau yang disebut berdzikir. Salah satu contoh, di dalam Al-Qur'an surat Al-Baqarah (2) ayat 152 disebutkan, Ingatlah Aku (Tuhan), maka Aku akan mengingatmu. Kepercayaan Islam memberi individu penafsiran yang bermakna saat menghadapi situasi sulit. Qur'an menerangkan secara jelas bahwa kesulitankesulitan di dunia adalah untuk menguji orang-orang yang beriman dan meminta mereka untuk bersabar saat menghadapi permasalahan-permasalahan yang datang. Sebagai contoh, Qur'an surat Al-Baqarah (2) ayat 155 mengatakan : "Kami mengujimu dengan sedikit ketakutan, kelaparan, dan kekurangan harta, jiwa dan buah-buahan, tetapi berikanlah kabar gembira pada mereka yang sabar menghadapi kesulitan". Menurut ajaran religius, peristiwa-peristiwa negatif dalam hidup mempunyai tujuan dan orang-orang diminta bersabar untuk mencapai pertumbuhan spiritual. 
PSISULA: Prosiding Berkala Psikologi

Vol. 1, 2019

E-ISSN: 2715-002X

Studi mengenai koping religius pada populasi muslim telah dilakukan (Ghorbani, Watson \& Khan, 2007; Khawaja, 2008). Perbedaan penggunaan koping religius antara orang-orang Mesir dan Swedia yang menderita kanker. Dilaporkan bahwa 92\% pasien kanker Mesir menyuarakan keyakinan bahwa Tuhan akan membantu mereka, sementara hanya 37\% pasien kanker Swedia menyatakan hal yang sama. Mehta (1997) dalam studi kualitatif pada penduduk muslim yang sudah tua di Malaysia melaporkan bahwa para lansia mengkaitkan proses penuaan mereka dan penurunan fisik yang menyertainya sebagai kehendak Tuhan. Banyak responden menyatakan bahwa mereka membaca ayat-ayat Al-Qur'an untuk mengelola sakit kepala yang mereka alami.

Menurut Pargament (dalam Alflakseir dan Coleman, 2009) kegiatan koping religius mewakili lima fungsi keagamaan, yaitu pencarian makna, pencarian untuk penguasaan dan kontrol, pencarian untuk kenyamanan kepada Allah, mencari keintiman dan kedekatan kepada Allah, dan mencari perubahan hidup.

Banyak studi telah dilakukan untuk mengembangkan koping religius untuk muslim. Khan dan Watson (2006) telah mengembangkan RCOPE (Religious Coping Scale) dengan subjek muslim Pakistan. Abu Raiya ( dalam Pargament, Stein, \& Mahoney 2008) membuat PMIR (Psychological Measure of Islamic Religiousness) untuk mengukur praktek-praktek dan kepercayaan dalam islam. Jana-Masri dan Priester (2007) mendesain RolS ( Religiosity of Islam Scale), instrumen berbasis AlQuran untuk mengukur religius Islam. Alflakseir dan Coleman (2011) telah mengembangkan RCOPE (Religious Coping Scale) dengan responden subjek muslim Iran. RCOPE yang dikembangkan Coleman (2011) terdiri dari prkatek religius (religious practise), perasaan negatif terhadap Tuhan ( negative feeling toward God), penilaian kembali kebajikan ( benevolent reappraisal ), strategi koping religius pasif (passive religious strategy), dan strategi koping religius aktif (active religious coping strategy) yang semua aitem-aitemnya disesuaikan dengan konteks Islam. 
PSISULA: Prosiding Berkala Psikologi

Vol. 1, 2019

E-ISSN: 2715-002X

\section{Metode}

Variabel pada penelian ini, variabel bebas adalah koping religius dan variabel tergantungnya adalah stres guru. Subjek penelitian ini berjumlah dari 71 orang guru, terdiri dari 24 orang guru SMA Sultan Agung 3 dan 47 orang guru SMA Sultan Agung 1 Semarang. Teknik pengambilan sampel dalam penelitian ini menggunakan purposive sampling, yaitu teknik pengambilan sekelompok subjek yang didasarkan atas ciri-ciri atau sifat-sifat tertentu yang dipandang mempunyai sangkut paut yang erat dengan ciri-ciri atau sifat-sifat populasi yang telah diketahui sebelumnya (Hadi, 2000). Ciri-ciri subjek penelitian ini adalah : Guru SMA Sultan Agung Semarang dan telah bekerja minimal 2 tahun. Penelitian ini dilakukan dengan cara single trial administration, yaitu penelitian dengan pengambilan data satu kali.

\section{Pengumpulan Data}

Teknik pengumpulan data menggunakan skala stres kerja guru dan skala koping religius. Skala stres kerja guru mengacu pada aspek-aspek stres kerja guru yang dikemukakan oleh Loekmono (1999) yang terdiri dari aspek : 1) Perilaku peserta didik, 2) Suasana pekerjaan, 3) Tekanan waktu, 4) Etos kerja. Skala stres kerja guru berjumlah 27 aitem, yang mempunyai indeks daya beda bergerak dari 0,315 sampai 0,562, dengan koefisien reliabiltas alpha sebesar 0,890. Skala koping religius memakai skala adaptasi dari RCOPE Alflakseir dan Coleman (2011) yang berjumlah 22 aitem, dengan reliabilitas masing-masing subskala : 1) aspek praktek religius, 0,890, 2) aspek perasaan negatif terhadap Tuhan, 0,720, 3) aspek penilaian kembali kebajikan, 0,790,4) aspek strategi koping pasif 0,720 , dan aspek strategi koping aktif 0,790 .

Data Demografi

\begin{tabular}{clc}
\hline \multirow{2}{*}{ Jenis Kelamin } & Laki-Laki & 33 \\
& Perempuan & 38 \\
\hline \multirow{2}{*}{ Usia } & $23-30$ & 17 \\
& $31-40$ & 13 \\
& $41-50$ & 20 \\
& $51-60$ & 21 \\
\hline PendidikanTerkahir & SLTP & 1
\end{tabular}


PSISULA: Prosiding Berkala Psikologi

Vol. 1, 2019

E-ISSN: 2715-002X

\begin{tabular}{clc} 
& S1 & 58 \\
& S2 & 12 \\
\hline \multirow{3}{*}{ Lama Bekerja } & 2 bulan -15 tahun & 35 \\
& 16 tahun -30 tahun & 30 \\
& 31 tahun -45 tahun & 6 \\
\hline & V a & 14 \\
& IV b & 1 \\
PANGKAT & III a & 2 \\
& III b & 2 \\
& III c & 7 \\
& III d & 11 \\
& GTT & 34 \\
\hline \multirow{2}{*}{ SERTIFIKASI } & Bersertifikasi & 38 \\
& TidakBersertifikasi & 33 \\
\hline \multirow{2}{*}{ STATUS } & Menikah & 56 \\
& BelumMenikah & 15 \\
\hline
\end{tabular}

\section{Hasil}

\section{Uji Asumsi}

Analisis data dilakukan dengan menggunakan SPSS 20. Sebelumnya dilakukan uji asumsi yang berupa uji normalitas data dan uji linearitas.

Tabel 1. Hasil Uji Normalitas

\begin{tabular}{llllll}
\hline \multicolumn{1}{c}{ Variabel } & Mean & $\begin{array}{c}\text { Standar } \\
\text { Deviasi }\end{array}$ & KS-Z & Sig. $p$ & Keterangan \\
\hline Stres Guru & 50,70 & 8,07 & 0,953 & $0,324>0,05$ & Normal \\
Koping Religius & 68,38 & 5,35 & 0,892 & $0,405>0,05$ & Normal \\
\hline
\end{tabular}

Berdasarkan uji normalitas terhadap skala stres guru diperoleh nilai $\mathrm{KS}-\mathrm{Z}=0,953$ dengan taraf signifikansi 0,324 ( $p>0,05)$. Hasil ini menunjukkan bahwa sebaran data stres guru terdistribusi normal. Sedangkan uji normalitas terhadap skala koping religius diperoleh nilai KS-Z $=0,892$ dengan taraf signifikansi $0,405(p>0,05)$, hasil ini menunjukkan sebaran data koping religius juga terdistribusi secara normal.

Selain uji normalitas, dilakukan uji linearitas untuk mengetahui apakah kedua variabel yang diteliti memiliki hubungan yang linear atau tidak. Uji linearitas dalam penelitian ini menggunakan teknik uji Flinier. Berdasarkan uji linearitas diperoleh Flinier $=52,814$ dengan signifikansi $p=0,000(P<0,01)$. Hal ini 
PSISULA: Prosiding Berkala Psikologi

Vol. 1, 2019

E-ISSN: 2715-002X

menunjukkan bahwa variabel stres guru dan koping religius terdapat hubungan yang linear.

\section{Uji Hipotesis}

Uji hipotesis dilakukan menggunakan teknik korelasi Product Moment dari Karl Pearson, diperoleh nilai $r_{x y}=-0,540$ dengan signifikansi $0,000(p<0,005)$. Hasil tersebut menunjukkan ada hubungan negatif yang signifikan antara koping religius dan stres guru. Artinya semakin tinggi koping religius yang dimiliki oleh guru maka semakin rendah stres yang dialaminya, sebaliknya semakin rendah koping religius yang dimiliki maka semakin tinggi stres yang dialaminya. Pada penelitian ini didapatkan nilai R sebesar 0,540, dan koefisien determinasinya adalah 0, 292. Koefisien determinasi yang ditunjukkan oleh $\mathrm{R}$ square adalah 0,292, yang berarti variabel koping religius mempunyai kontribusi sebesar $29,2 \%$ terhadap variabel stres guru dan 70,8\% dipengaruhi faktor-faktor lain yang tidak diteliti dalam penelitian ini.

\section{Uji Data Tambahan}

Pada penelitian ini dilakukan uji data tambahan untuk melihat perbedaan stres kerja antara laki-laki dan perempuan.

Tabel 3. Deskripsi data stres guru

\begin{tabular}{lllll}
\hline & Jenis Kelamin & N & Mean & Std. Deviasi \\
\hline Stres Guru & Laki-laki & 33 & 50,48 & 9,941 \\
& Perempuan & 38 & 50,89 & 6,142 \\
\hline
\end{tabular}

Hasil uji beda menggunakan t-test diperoleh nilai $\mathrm{t}=0,212$ dengan signifikansi 0,833 ( $p>0,05$ ) menunjukkan bahwa tidak terdapat perbedaan stres guru antara laki-laki dan perempuan.

\section{Pembahasan}

Berdasarkan hasil uji hipotesis menggunakan teknik korelasi Product Moment dari Karl Pearson, diperoleh nilai $r x y=-0,540$ dengan signifikansi 0,000 ( $p$ $<0,005)$, maka hipotesis dalam penelitian ini diterima, yaitu terdapat hubungan 
PSISULA: Prosiding Berkala Psikologi

Vol. 1, 2019

E-ISSN: 2715-002X

negatif yang signifikan antara koping religius dan stres pada guru SMA Islam. Semakin tinggi koping religius yang dimiliki guru maka semakin rendah stresnya dan sebaliknya.

Pargament (1997) mengemukakan agama mempunyai dampak positif terhadap kesehatan mental. Agama dapat dikatakan mengurangi atau mencegah stres kehidupan, dan dapat menjadi koping yang efektif. Koenig (1994) mengungkapkan koping religius merupakan koping yang melibatkan penggunaan kognisi dan strastegi perilaku yang didasarkan pada kepercayaan atau praktekpraktek religi untuk mengelola stres emosional atau ketidaknyamanan fisik. Alflakseir dan Coleman (2011) berpendapat bahwa dalam ajaran Islam, keyakinan agama dan praktek-praktek religi dapat digunakan sebagai sumber daya untuk menghadapi situasi hidup yang sulit.

Menurut Alflakseir dan Coleman (2011) pada saat individu membutuhkan bimbingan dan pertolongan, Islam mengajarkan orang untuk bersabar, berdoa, percaya dan kembali kepada Tuhan. Pada saat individu menghadapi situasi yang sulit, kepercayaan Islam memberikan individu penafsiran yang bermakna. Keadaan yang sulit dalam kehidupan hanyalah untuk menguji orang-orang yang beriman, pertolongan dan kabar gembira akan diberikan pada mereka yang sabar menghadapinya. Hussain dan Cochcrane (2003) mengemukakan praktek menjalankan ibadah merupakan kebutuhan yang tulus untuk meminta pertolongan kepada Tuhan.

Kehendak Tuhan atau kasih sayang Tuhan dapat berbentuk dalam banyak hal, seperti penyakit, kematian, dan kerugian lainnya. Saat menghadapi situasi yang menekan tersebut individu akan mengambil pelajaran ( Pargament, 1997). Menghadapi perilaku anak didik, situasi kerja, tekanan waktu dan tetap harus menjaga etos kerja merupakan stres tersendiri bagi guru. Namun dengan mengambil pelajaran dan bersabar serta meminta pertolongan kepada Tuhan, halhal tersebut dapat disikapi dengan lebih baik.

Penelitian yang melibatkan subyek wanita muslim yang mengalami depresi menemukan bahwa koping yang bersifat religius merupakan strategi yang paling 
PSISULA: Prosiding Berkala Psikologi

Vol. 1, 2019

E-ISSN: 2715-002X

umum dilakukan. Banyak dari mereka menyatakan tetap ingin menjadi muslim yang baik dengan cara menjalankan sholat lima waktu secara rutin. Mereka juga berdoa untuk mencari pertolongan dan membaca banyak doa-doa yang berasal dari AlQur'an terutama untuk meminta perlindungan dari penyakitnya dan simtomsimtom yang menyertainya ( Hussain dan Cochrane, 2003).

Menurut Alflakseir dan Coleman ( 2010 ), pada aspek koping religius diantaranya adalah religius praktis, di mana individu cenderung melakukan ajaran agamanya seperti sholat dan berdoa ketika individu dihadapkan pada kondisi sulit yang mengakibatkan stres. Pada penelitian ini, subjek penelitian paling banyak menggunakan benelovent reappraisal ( dengan nilai mean 18,93) yaitu individu dapat mengambil pelajaran dari masalah yang dihadapi, dengan menanggapi sebuah permasalahan sebagai sesuatu yang bersifat baik, sehingga individu akan lebih mudah melakukan penyesuaian diri. Kemudian subjek penelitian juga menggunakan religious practise (dengan nilai mean 18, 85 ) di mana individu akan lebih banyak melakukan ajaran agamanya seperti sholat dan berdoa ketika individu dihadapkan pada kondisi sulit yang dapat mengakibatkan stres. Dengan melakukan hal tersebut individu dapat melewati masa-masa sulit yang ada, dan akan lebih mudah melakukan penyesuaian diri. Selanjutnya active religious coping juga dilakukan subjek ( dengan nilai mean 10, 85) yaitu individu akan cenderung menyelesaikan masalah sebisa mungkin, dan menyerahkan sisanya kepada Tuhan. Pada aspek passive religious coping dilakukan subjek penelitian ( dengan nilai mean 4,62), dalam hal ini subjek tidak melakukan upaya apapun, hanya menyerahkan segala sesuatunya kepada Tuhan.

Menurut Pargament (1997) saat menghadapi situasi yang sulit individu akan mengambil makna dari pelajaran yang ada, kematian, penyakit dan kerugian lainnya sebagai kehendak Tuhan atau kasih sayang Tuhan. Pada saat menghadapi berbagai macam tekanan Hussain dan Cochrane (2003) mengemukakan praktek menjalankan ibadah merupakan kebutuhan yang tulus untuk meminta pertolongan kepada Tuhan. Lebih lanjut Hussain dan Cochrane (2003) pada penelitiannya yang 
PSISULA: Prosiding Berkala Psikologi

Vol. 1, 2019

E-ISSN: 2715-002X

melibatkan subyek wanita muslim yang mengalami depresi mengemukakan bahwa koping yang bersifat religius merupakan strategi yang paling umum dilakukan.

\section{Kesimpulan}

Kesimpulan hasil penelitian ini ada hubungan negatif yang signifikan antara koping religius dengan stres pada guru, artinya semakin tinggi koping religius maka semakin rendah stres yang dialami dan sebaliknya. Pada guru hendaknya mempertahankan koping religius yang dimilikinya agar dapat menurunkan stres yang dialaminya.

\section{Daftar Pustaka}

Abraido-Lanza, A.F.,Vasques,E., \& Echeverria, S.E. 2004. En las Manos de Dios [in God's Hands]: Religious and other forms of coping among Latinos with arthritis. Journal of Consulting and Clinical Psychology, 72(1), 91-102.

Ancok, D. \& Suroso, F.N. 2008. Psikologi islam : Solusi islam atas problem-problem psikologi. Yogyakarta : Pustaka Pelajar.

Alflakseir, A. \& Coleman,P.G. 2011. Initial developmental of the Iranian religious coping scale. Muslim Mental Health. Vol 6, 1, 21-27.

Betoret, F.D. 2006. Stressor, self-efficacy, coping resources, and burnout among secondary school teachers in Spain. Educational psychology : An International Journal of Experimental Educational Psychology, 26, 519-539.

Betoret, F.D. 2009. Self-efficacy, school resouces, job stressors and burnout among spanish primary and secondary school teachers : A stuctural equation approach. Educational Psychology, 29, 45- 68.

Blix, A.G., \& Mitchell, B.M. 2004. Occupational stress among university teachers. Educational Research, Vol 36, 2, 157-169.

Chan, A.H.S, Chen,K., \& Chong, E.Y.L. Work stres of teachers from primary and secondary schools in Hong Kong. 2010. Proceeding of the International MultiConference of Engineers and Computer Scientists, Vol III, IMECS 2010, March 17-19. Hong Kong. ISSN : 2078 - 0966 (Online)

Curtis, A.J.2000. Health psychology. New York : Routlegdge.

Collie, R.J., Shapka, J.D., \& Perry, N.E. 2012. School climate and social emotional learning : Predicting teacher stress, job satisfaction, ang teaching efficacy. Journal of Educational Psychology, 104, 1189-1204. 
Fernet, C., Guay, F., Senecal, C., \& Austin, S. 2012. Predicting intraindividual changes in teacher burnout : The role of perceived school environmental and motivational factors. Teaching and Teacher Education, 28, 514-525.

Ghorbani, N., Watson,P.J., \& Khan, Z.H. (2007). Theoritical, empirical, and potential ideological dimensions of using westren conceptualizations to measure Muslim religious commitments. Journal of Muslim Mental Health, 2, 113131.

Gosling, S.D, Rentfrow, P.J., \& Swann, W.B.Jr. 2003. A very brief measure of the big five personality domains, Journal of Research in Personality, 37, 504- 528.

Hakanen, J.J., Bakker, A.B., \& Schaufeli, W.B.2006. Burnout and work engagement among teachers. Journals of School Psychology, 43, 495-513.

Hussain, F.A., \& Cochrane, R. 2003. Living with depression : Coping strategies used by South Asian women living in the UK suffering from depression. Mental Health, Religion \& Culture, 2, 177-188.

Jana-Masri, A., \& Priester, P.E. 2007. The development and validation of a Qur'an based instrument to assess Islamic religiosity: The Religiosity of Islam Scale. Journal of Muslim Mental Health, 2, 177-188.

Kasberger, E.R. 2002. A correlation study of post-divorce adjustment and religious coping strategiesin young adult of divorced families. Second Annual.Undergraduate Research Symposium Charish Institute of Winconsin Lutheran College. Milwaukee, WI 53226. April, 27-28, 2002.

Khan, A., Shah, I.M., Khan, S., \& Gul, S. 2012. Teachers' stress, performance, and resources. The moderating effects of resources on stress and performance. International Review of Social Sciences and Humanities, Vol.2, No.2, 21-29, ISSN : 2248 - 9010 ( Online).

Khan, Z.H., \& Watson, P.J. 2006. Construction of the Pakistani Religious Coping Practices Scale : corelations with religious coping, religious orientation, and reactions to stress among Muslim university students. International Journal for the Psychology of Religion, 16, 101-112.

Khawaja, N.G. 2008. An ivestigation of the factor structure and psychometric properties of the COPE scale with a Muslim migrant population in Australia. Journal of Muslim Mental Health, 3, 177-191.

Klassen, R., \& Chiu, M.M. 2010. The occupational commitment and intention to quit of practicing and pre-service teachers : Influence of self-efficacy, job stress, and teaching context. Contemporary Educational Psychology, 36, 114 - 129.

Klassen, R., wilson,E., Siu, A.F.Y., Hannok, W., Wong, M.W., Wongsri,N., Sonthisap, P., Pibulchol, C., Buranachaitavee, Y., \& Jansem.A. 2013. Preservice teachers's work stress, self-efficacy, and occupational commitment in four countries. European Journal of Psychology of Education, 28, 1289 - 1309. 
PSISULA: Prosiding Berkala Psikologi

Vol. 1, 2019

E-ISSN: 2715-002X

Koenig, H.G. 1994. Aging and God. Spiritual pathways to mental health in midlife \& later years. New-York : Haworth Pastoral Press.

Kyriacou, C. 1987. Teacher stress and burnout : An international review.Educational Research, 29, 146-152.

Kyriacou, C. 2001. Teacher stress : Directions for future research. Educational Review, 53, 1, 27-35.

Liu, S., \& Onwuegbuzie, A.J. 2012. Chinesse teachers' work stres and their turnover intention. International journal of Educational Research, 53, 160-170.

Mehta, K.K. 1997. The impact of religious beliefs and practises on aging : A crosscultural comparison. Journal of Aging Studies, 11, 101 - 114.

Nevid, J.S., Rathus, S.A., \& Greene, B. 2005. Psikologi Abnormal. Jilid 1. Alih bahasa : Tim fakultas psikologi UI. Jakarta : Penerbit Erlangga.

Pargament, K.I. 1997. The psychology of religion and coping. New-York : Guilford Press.

Pargament, K.I., Smith, B.W., Koenig, H.G., \& Perez, L. 1998. Pattern of positive and negative religious coping with major life stressors. Journal for the Scientific Study of Religion, 37, 710-724.

Pargament, K.I., Tarakeshwar, N., Ellison, C.G., \& Wulf, K.M. 2001. Religious coping among the religious: The relationships beetwen coping religious and wellbeing in a national sample of presbytarian clergy, elders, \& members. Journal of the Scientific Study of Religion, 40, 3, 497-513.

Rammohan, A., Rao, K., \& Subbakhrisna, D.K. 2002. Religious coping and psychological well-being in careers of relatives with schizophrenia. Acta Psychiatrica Scandinavica, 105, 5, 356-362.

Skaalvik, E.M., \& Skaalvik, S. 2011. Teacher job satisfaction and motivation to leave the teaching proffesion : relations with school context, feeling of belonging, and emotional exhaustion. Teaching \& Teacher Education, 27, 1029-1038.

Skaalvik, E.M., \& Skaalvik, S. 2013. School goal structure : Associations with students perception of their teachers as emotionally supportive, academic self-concept, intrinsic motivation, and help seeking behavior. International Journal of Educational Research, 61, 5-14.

Sugiyono. 2008. Metode penelitian kuantitatif, kualitatif dan R\&D. Bandung : Alfa Beta.

Taylor, S.E. 1995. Health psychology. New York : McGraw Hill Inc.

Toisuta, D., \& Loekmono, J.T. 2017. Hubungan kepuasan kerja, stres guru dengan kebahagiaan guru pendidikan agama Sekolah Menengah Atas di kota Ambon. Satya Widya : Jurnal Penelitian Pengembangan Kependidikan, 3, 1, 11-28. 